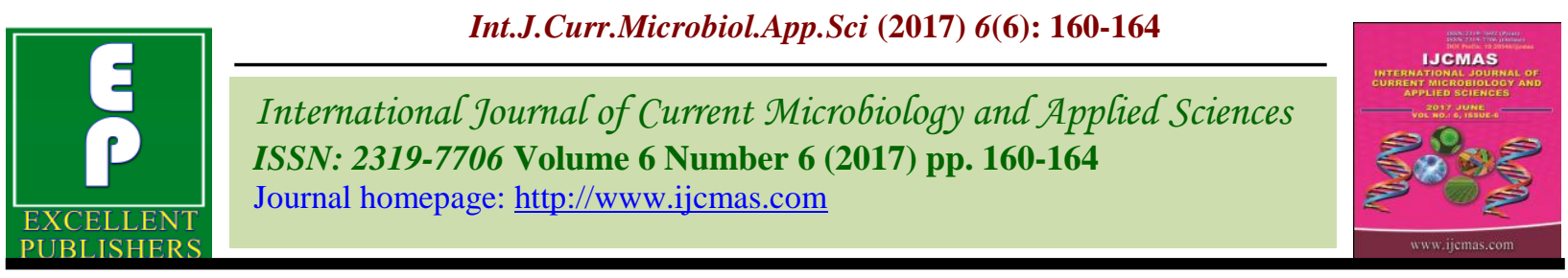

Original Research Article

https://doi.org/10.20546/ijcmas.2017.606.019

\title{
Response of mango (Mangifera indica L.) Cultivars to Agro-Chemicals with Respect to Physical Parameters
}

\author{
R.K. Yadav*, D.K. Sarolia, R.A. Kaushik, N.S. Devra and G.L. Yadav \\ ${ }^{1}$ Department of Horticulture, Rajasthan College of Agriculture (MPUAT), Udaipur, \\ Rajasthan, India \\ ${ }^{2}$ Central Institute for Arid Horticulture, Bikaner, Rajasthan, India \\ *Corresponding author
}

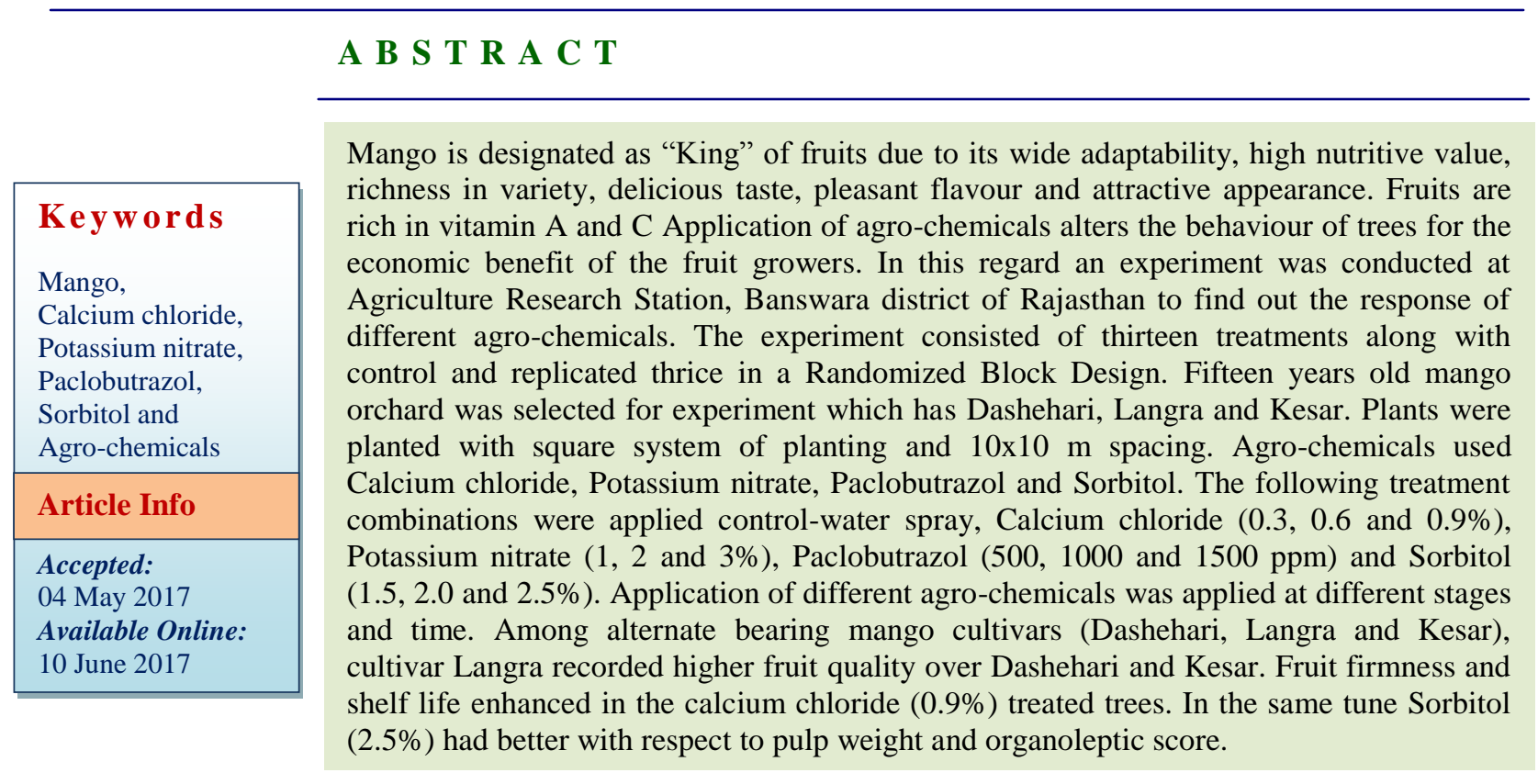

\section{Introduction}

Mango (Mangifera indica L.) is one of the oldest and choicest tropical fruits of the world and is rightly designated as "King" of fruits. It is belongs to family Anacardiaceae and indigenous to Indo-Burma region (Popenoe, 1920 and Mukherjee, 1951) and most outstanding among the tropical fruits of India. Due to its wide adaptability, high nutritive value, richness in variety, delicious taste, pleasant flavour, attractive appearance, it enjoys the unique popularity among the masses and classes (Anonymous, 1998).
Fruits are rich in vitamin A (1082 IU/100g) and also vitamin C (36.4 $\mathrm{mg} / 100 \mathrm{~g})$ (Anonymous, 2011). The area under cultivation in India of mango is 2.51 mha and production is $18.43 \mathrm{mt}$ with the productivity of $7.3 \mathrm{MTha}^{-1}$ (Anonymous, 2014). It is grown in almost all the states.

Maharashtra tops in total area and Uttar Pradesh ranks first production wise. In Rajasthan area of mango crop is 5,610 ha and production is 79,900 MT with the 
productivity of $14.24 \mathrm{MTha}^{-1}$ (Anonymous, 2014). Mango is commonly cultivated in Banswara, Dungarpur, Chittorgarh, Pratapgarh, Udaipur, Bhilwara, Dhaulpur and Dausa districts of Rajasthan.

The mango tree is long-lived, medium to large (10 to $40 \mathrm{~m}$ in height) with profuse, wide-spreading feeder roots, the tree also sends down many anchor roots, which penetrate several feet of soil $(6 \mathrm{~m})$. The inflorescence is a many branched panicle borne at shoot terminals, 2.5 to 16 inches long (6.4 to $40.6 \mathrm{~cm}$ ), possessing from 550 to more than 4,000 flowers. Flowers are monoecious, polygamous and small, pinkish-white, with the majority staminate and the remainder perfect. Its flowers are borne on terminal pyramidal panicles 10-40 cm long, each flower is small and white with five petals 5$10 \mathrm{~mm}$ long, glabrous, the inflorescence is rigid and erect and is widely branched, usually densely flowered. Both male and perfect flowers are found within a single inflorescence the pistil aborts in male flowers. It is believed that the flowers are crosspollinated by houseflies. The fruit takes three to six months to ripen from fruit set.

Application of agro-chemicals (for regular flowering and improve fruit set) alter the behavior of trees for the economic benefit of the fruit growers. Control of vegetative vigor, stimulation of flowering, regulation of crop load, reduction of fruit drop, delay or stimulation of fruit maturity and ripening are important examples of processes in fruit and fruit trees that can be regulated with exogenous applications of agro-chemicals. As $\mathrm{KNO}_{3}$ is suggested to induce ethylene production and efficacy of $\mathrm{KNO}_{3}$ is suppressed by ethylene biosynthesis inhibiters, the involvement of ethylene appear an important factor in mango flower process (Upreti et al., 2014). Calcium compound improve firmness, delay fruit ripening, storability, better skin and pulp colour (Anjum and Ali, 2004) and paclobutrazol help for regular bearing in biennial habits of mango cultivars.

\section{Materials and Methods}

Experiment was conducted in Banswara district of Rajasthan. The region falls under agro-climatic zone IVb "Humid Southern Plain Zones of Rajasthan' at an altitude of 302 metre above mean sea level and lies between $23^{\circ} 11^{\prime} \mathrm{N}$ to $23056^{\prime} \mathrm{N}$ latitude and $73^{\circ} 58^{\prime} \mathrm{E}$ to $74049^{\prime} \mathrm{E}$ longitude. This region has a typical sub-tropical climate, characterized by mild winters and summers. Soils predominantly reddish medium textured well drained calcareous, shallow on hills, deep soils in valleys. Fifteen years old mango orchard was selected for experiment which have Dashehari, Langra and Kesar. Plants were planted with square system of planting and $10 \times 10 \mathrm{~m}$ spacing. Agro-chemicals Calcium chloride, Potassium nitrate, Paclobutrazol and Sorbitol were used.

The following treatment combinations were appliedcontrol-water spray,Calcium chloride $(0.3 \%, 0.6 \%$ and $0.9 \%)$ Potassium nitrate (1\%, 2\% and 3\%) Paclobutrazol (500ppm, $1000 \mathrm{ppm}$ and $1500 \mathrm{ppm})$ Sorbitol (1.5\%, $2.0 \%$ and 2.5\%). Stage and time of application of different agro-chemicals during 2012-13 and 2013-14: calcium chloride at one month prior to harvesting (May, 7-8), potassium nitrate at marble size stage (February, 27 to March, 01), paclobutrazol at fruit bud differentiation stage (October, 11) and sorbitol at pea nut size (January, 19).

Fruit firmness, fruit surface and pulp colour, pulp, stone and peel weight, shelf life of fruit at room temperature, pulp recovery, organoleptic score, these observations were recorded as per standard methods. 


\section{Results and Discussion}

At maturity cultivar Langra had showed maximum fruit firmness $\left(7.63 \mathrm{~kg} / \mathrm{cm}^{-2}\right)$ followed by Dashehari $\left(7.15 \mathrm{~kg} / \mathrm{cm}^{-2}\right)$ and minimum fruit firmness found $\left(6.81 \mathrm{~kg} / \mathrm{cm}^{-2}\right)$ in cultivar Kesar. This probably due to the fact that calcium enhances fruit firmness which leads to slower hastening extends the shelf-life. These results are in accordance with earlier reports of Gill et al., (2005).

The application of $0.9 \% \mathrm{CaCl}_{2}$ was observed maximum fruit firmness $\left(7.98 \mathrm{~kg} / \mathrm{cm}^{-2}\right)$. The fruit peel colour of Kesar liked very much (8.16) by judges. Likewise, the fruit pulp colour was also observed in same method and almost similar trend as of fruit peel colour, cultivar Kesar like very much (8.46).

Result in the line with the findings of Singh (2002). Among agro-chemicals, 3\% $\mathrm{KNO}_{3}$ was observed good (7.93). Likewise, the fruit pulp colour was also observed the same way and trend, $3 \% \mathrm{KNO}_{3}$ was observed as like very much (7.93). Colour of peel and pulp higher in $\mathrm{KNO}_{3}$ treatment probably due to improved photosynthates assimilation, their translocation from leaves to fruit and increased enzyme activation (Kanai et al., 2007) and reducing sugar by sorbitol application.

Highest pulp weight $159.69 \mathrm{~g}$ was recorded in Kesarand minimum (139.86 g) in Dashehari. Application of water (control) showed the maximum pulp weight $164.07 \mathrm{~g}$, whereas, the lowest $(143.39 \mathrm{~g})$ was obtained by the application of PBZ 500 ppm.

The minimum stone weight $(21.68 \mathrm{~g})$ was recorded in Dashehari and maximum (28.66 g) in Kesar. The maximum peel weight (25.32 g) was recorded in Langra and minimum $(16.52 \mathrm{~g})$ in Kesar. Kesar had highest shelf life of fruits at room temperature (11.30 days) and minimum (8.99 days) was observed with
Dashehari. Genetic makeup of cultivar directly influence the shelf life of fruits it's the varietal character in present study cultivar Kesar recorded about 2.30 days higher shelf life over Dashehari.

The maximum shelf life of fruits at room temperature (13.43 days) in mango fruit was recorded with the spray of $\mathrm{CaCl}_{2} 0.9 \%$ and minimum (6.18 days) observed in trees which treated with water spray. Agro-chemical $\mathrm{CaCl}_{2}$ spray was also enhanced the shelf life and $\mathrm{CaCl}_{2} \quad 0.9 \%$ recorded just two times higher shelf life over water spray.

The maximum shelf life of fruits at room temperature 15.95 days was obtained under Kesar $+\mathrm{CaCl}_{2}$ 0.9\% whereas, the lowest $(5.35$ days) in Dashehari + water spray. Interaction effect of cultivars and agro-chemicals Kesar + $\mathrm{CaCl}_{2}$ 0.9\% was recorded about 10.5 days more shelf life over Dashehari + water spray.

The outcome of present study is also in a line of Babul and Rahim (2012). This is probably due to the fact that calcium enhances fruit firmness which leads to slower hastening extends the shelf-life. The significantly highest pulp recovery $(77.84 \%)$ was noted in Kesar and lowest $(74.04 \%)$ was recorded in Langra.

The maximum organoleptic score 8.44 was observed with Dashehari and the minimum was obtained in Kesar. The highest organoleptic score of7.92 was recorded with sorbitol $2.5 \%$ while, minimum (6.17) in water spray. As indicated earlier that under paclobutrazol optimum concentration which establish proper source to sink relationship that accumulate and utilization organic matter i.e., acidity and ascorbic acid that improve over all fruit quality (organoleptic score). The findings obtained in the present investigation can be compared to those obtained by Omayama et al., (2010) in guava (Table 1). 
Table.1 Response of mango cultivars to agro-chemicals with respect to physical parameter

\begin{tabular}{|c|c|c|c|c|c|c|c|c|c|}
\hline Treatments & $\begin{array}{c}\text { Fruit } \\
\text { firmness } \\
\left(\mathrm{kg} / \mathrm{cm}^{-2}\right)\end{array}$ & $\begin{array}{c}\text { Fruit } \\
\text { surface } \\
\text { colour } \\
\text { (score out of 9) } \\
\end{array}$ & $\begin{array}{c}\text { Fruit pulp } \\
\text { colour } \\
\text { (score out of } \\
9 \text { ) }\end{array}$ & $\begin{array}{c}\text { Pulp } \\
\text { weight } \\
\text { (g) }\end{array}$ & $\begin{array}{l}\text { Stone } \\
\text { weight } \\
\text { (g) }\end{array}$ & $\begin{array}{l}\text { Peel } \\
\text { weight } \\
\text { (g) }\end{array}$ & $\begin{array}{c}\text { Shelf life of } \\
\text { fruits at room } \\
\text { temperature } \\
\text { (days) } \\
\end{array}$ & $\begin{array}{c}\text { Pulp } \\
\text { recovery } \\
(\%)\end{array}$ & $\begin{array}{c}\text { Organ } \\
\text { oleptic } \\
\text { score }\end{array}$ \\
\hline \multicolumn{10}{|l|}{ Varieties } \\
\hline $\mathrm{V}_{1}$ (Dashehari) & 7.15 & 7.23 & 7.18 & 139.86 & 21.68 & 20.38 & 8.99 & 76.88 & 8.44 \\
\hline $\mathrm{V}_{2}$ (Langra) & 7.63 & 6.51 & 6.42 & 147.50 & 26.33 & 25.32 & 9.99 & 74.04 & 6.90 \\
\hline $\mathrm{V}_{3}$ (Kesar) & 6.81 & 8.16 & 8.46 & 159.69 & 28.66 & 16.52 & 11.30 & 77.84 & 6.47 \\
\hline SEm \pm & 0.04 & 0.04 & 0.03 & 1.01 & 0.36 & 0.25 & 0.06 & 0.24 & 0.03 \\
\hline $\mathrm{CD}$ at $5 \%$ & 0.11 & 0.11 & 0.10 & 2.82 & 1.00 & 0.69 & 0.17 & 0.68 & 0.09 \\
\hline \multicolumn{10}{|l|}{ Agro-chemicals } \\
\hline $\mathrm{T}_{0}$ (Control) WS & 5.43 & 5.77 & 6.18 & 164.07 & 27.03 & 20.23 & 6.18 & 77.63 & 6.17 \\
\hline $\mathrm{T}_{1}\left(\mathrm{CaCl}_{2} 0.3 \%\right)$ & 7.70 & 7.52 & 7.53 & 144.84 & 24.69 & 20.14 & 10.98 & 76.38 & 6.87 \\
\hline $\mathrm{T}_{2}\left(\mathrm{CaCl}_{2} 0.6 \%\right)$ & 7.88 & 7.58 & 7.62 & 145.24 & 24.92 & 20.33 & 11.87 & 76.20 & 6.95 \\
\hline $\mathrm{T}_{3}\left(\mathrm{CaCl}_{2} 0.9 \%\right)$ & 7.98 & 7.65 & 7.68 & 145.57 & 25.05 & 20.43 & 13.43 & 76.12 & 7.05 \\
\hline $\mathrm{T}_{4}\left(\mathrm{KNO}_{3} 1 \%\right)$ & 7.38 & 7.78 & 7.75 & 147.95 & 25.59 & 20.88 & 9.37 & 76.09 & 7.15 \\
\hline $\mathrm{T}_{5}\left(\mathrm{KNO}_{3} 2 \%\right)$ & 7.48 & 7.85 & 7.83 & 149.18 & 25.21 & 21.06 & 10.35 & 76.36 & 7.22 \\
\hline $\mathrm{T}_{6}\left(\mathrm{KNO}_{3} 3 \%\right)$ & 7.62 & 7.93 & 7.93 & 149.20 & 26.21 & 21.25 & 10.78 & 75.82 & 7.28 \\
\hline $\mathrm{T}_{7}(\mathrm{PBZ}$ 500ppm) & 7.12 & 6.92 & 6.93 & 143.39 & 24.39 & 20.05 & 8.93 & 76.33 & 7.38 \\
\hline $\mathrm{T}_{8}(\mathrm{PBZ} 1000 \mathrm{ppm})$ & 7.22 & 6.98 & 7.03 & 143.71 & 24.55 & 20.14 & 9.15 & 76.25 & 7.48 \\
\hline $\mathrm{T}_{9}(\mathrm{PBZ} 1500 \mathrm{ppm})$ & 7.32 & 7.12 & 7.15 & 144.17 & 24.67 & 20.21 & 9.55 & 76.19 & 7.58 \\
\hline $\mathrm{T}_{10}($ Sorbitol $1.5 \%)$ & 6.75 & 7.17 & 7.22 & 152.17 & 26.29 & 21.51 & 9.58 & 76.04 & 7.63 \\
\hline $\mathrm{T}_{11}$ (Sorbitol 2.0\%) & 6.82 & 7.27 & 7.30 & 153.40 & 26.67 & 21.66 & 10.43 & 75.92 & 7.80 \\
\hline $\mathrm{T}_{12}($ Sorbitol $2.5 \%)$ & 6.88 & 7.37 & 7.43 & 154.30 & 26.99 & 21.71 & 10.58 & 75.95 & 7.92 \\
\hline SEm \pm & 0.082 & 0.080 & 0.071 & 2.100 & 0.748 & 0.518 & 0.123 & 0.508 & 0.068 \\
\hline $\mathrm{CD}$ at $5 \%$ & 0.230 & 0.223 & 0.199 & 5.868 & NS & NS & 0.345 & NS & 0.191 \\
\hline
\end{tabular}


In conclusion, among alternate bearing mango cultivars (Dashehari, Langra and Kesar), cultivar Langra recorded higher fruit quality over Dashehari and Kesar. With respect to good fruit quality were observed in Kesar but poor yielder. Thus, Langra and Dashehari cultivars are promising in this region.

Fruit firmness, shelf life enhanced in the calcium chloride $(0.9 \%)$ treated trees. In the same tune application of Sorbitol (2.5\%) had better with respect to pulp weight and organoleptic score. Cultivars and agrochemicals showed significant effect on shelf life of fruits was obtained under Kesar + $\mathrm{CaCl}_{2} \quad 0.9 \%$. Thus, cultivar Langra and agrochemical paclobutrazol 1500 ppm were better for quality in mango crop production.

\section{References}

Anjum, Muhammad Akbar and Ali, Hakoomat, 2004. Effect of various calcium salts on ripening of mango fruits. Journal of Research (Science), Bahauddin Zakariya University, Multan, Pakistan, 15(1): 45-52.

Anonymous 1998. The mango. Bulletin of Central Institute for Sub-tropical Horticulture, Lucknow, p.1.

Anonymous 2011. USDA National Nutrient Database for Standard Reference, Release 24.

Anonymous 2014. National Horticulture Board database,http://nhb.gov.in

Babul, C. Sarker and Rahim, M.A. 2012. Vegetative growth, harvesting time, yield and quality of mango (Mangifera indica L.) as influenced by soil drench application of paclobutrazol.

Gill, P.S., Nav, S. and Jawandha, S.K. 2005. Post-harvest handling of mango. Revi. Punjab Agriculture University, 4: 150160.

Kanai, S., Ohkura, K., Adu-Gyamfi, J.J., Mohapatra, P.K., Nguyen, N.T., Saneoka, H. and Fujita, K. 2007. Depression of sink activity precedes the inhibition of biomass production in tomato plants subjected to potassium deficiency stress. Journal of Experimental Botany, 58: 2917-2928.

Mukherjee, S.K. 1951. Origin of Mango. Indian Journal of Genetics and Plant Breeding, 11: 49-56.

Omayama, M.A.A., Eman, E., Abed, A.S.E., Abed and El-Naggar, M.A.A. 2010. Influence of some post-harvest treatments on guava fruits. Egyptian Journal of Food, 50: 255-259.

Popenoe, W. 1920. Manual of Tropical and Subtropical Fruits, p. 474. The Macmillan Co., New York.

Singh, S. 2002. Evaluation of mango cultivars for their flowering, fruiting and fruit quality attributes. Progressive Horticulture, 34(2):240-243.

Upreti, K.K., Shivu Prasad, S.R. and Bindu, G.V. 2014. Regulatory roles of phytohormones and carbohydrates of flowering in mango. National seminarcum-workshop, 24-26 May, 2014. p. 164-172.

\section{How to cite this article:}

Yadav, R.K., D.K. Sarolia, R.A. Kaushik, N.S. Devra and Yadav, G.L. 2017. Response of mango (Mangifera indica L.) Cultivars to Agro-Chemicals with Respect to Physical Parameters. Int.J.Curr.Microbiol.App.Sci. 6(6): 160-164.

doi: https://doi.org/10.20546/ijcmas.2017.606.019 